OPEN ACCESS

Edited by:

Melissa de Vel-Palumbo,

Flinders University, Australia

Reviewed by:

Angela Jones,

Texas State University, United States

Joshua D. Behl,

Flagler College, United States

${ }^{*}$ Correspondence:

Logan Ewanation

logan.ewanation@carleton.ca

Specialty section

This article was submitted to

Forensic and Legal Psychology,

a section of the journal

Frontiers in Psychology

Received: 22 April 2021

Accepted: 02 August 2021

Published: 03 September 2021

Citation:

Ewanation L and Maeder EM

(2021) The Interactive Effects of Race and Expert Testimony on Jurors'

Perceptions of Recanted

Confessions.

Front. Psychol. 12:699077.

doi: 10.3389/fpsyg.2021.699077

\section{The Interactive Effects of Race and Expert Testimony on Jurors' Perceptions of Recanted Confessions}

\author{
Logan Ewanation ${ }^{1 *}$ and Evelyn M. Maeder ${ }^{2}$ \\ ${ }^{1}$ Department of Psychology, Carleton University, Ottawa, ON, Canada, ${ }^{2}$ Institute of Criminology and Criminal Justice, \\ Carleton University, Ottawa, ON, Canada
}

We examined the effect of defendant race and expert testimony on jurors' perceptions of recanted confessions. Participants (591 jury-eligible community members) read a first-degree murder trial transcript in which defendant race (Black/White) and expert testimony (present/absent) were manipulated. They provided verdicts and answered questions regarding the confession and expert testimony. When examining the full sample, we observed no significant main effects or interactions of defendant race or expert testimony. When exclusively examining White participants, we observed a significant interaction between expert testimony and defendant race on verdicts. When the defendant was White, there was no significant effect of expert testimony, but when the defendant was Black, jurors were significantly more likely to acquit when given expert testimony. These findings support the watchdog hypothesis, such that White jurors are more receptive to legally relevant evidence when the defendant is Black.

Keywords: juror decision-making, recanted confessions, watchdog hypothesis, expert testimony, juries, confession evidence, defendant race

\section{INTRODUCTION}

Empirical research indicates that suspects falsely confess to crimes for a variety of reasons (Kassin and Kiechel, 1996; King and Snook, 2009). According to the Innocence Project (2021), false confessions ${ }^{1}$ were involved in approximately a quarter of the cases that have been exonerated through DNA evidence. However, confessions remain one of the most influential forms of evidence in the courtroom (Kassin and Neumann, 1997; Lieberman et al., 2008). Although expert witnesses are sometimes used to safeguard against issues with confession evidence, the effect of expert testimony on jurors' perceptions of recanted confessions is unclear (Moffa and Platania, 2007; Blandon-Gitlin et al., 2011). Further, jurors' perceptions of recanted confessions may depend upon the suspect's race, as jurors perceive confessions as more voluntary when the defendant belongs to a racial minority (Pickel et al., 2013).

Most research focusing on the interaction between juror and defendant race has found that jurors are more lenient toward same-race defendants (see Devine and Caughlin, 2014). However, Sargent and Bradfield (2004) found that White mock jurors were more sensitive to legally relevant

\footnotetext{
${ }^{1}$ The Innocence Project includes false admissions and other forms of self-incrimination in their definition of false confessions.
} 
evidence in a trial transcript when the defendant was Black as compared to White. These authors argued that White jurors may attend to evidence more closely when the defendant is Black in an effort to serve as "watchdogs" against racism (termed the watchdog hypothesis). In a case in which a defendant has recanted their confession, the watchdog hypothesis would suggest that jurors may be more receptive to expert testimony (regarding factors that increase the likelihood of false confessions) when the defendant is Black, resulting in fewer guilty verdicts. The current study examines the interactive effects of defendant race and expert testimony on jurors' perceptions of recanted confessions.

\section{Confession Evidence}

Empirical research has demonstrated that individuals may falsely confess to crimes that they did not commit (e.g., Kassin and Kiechel, 1996; Redlich et al., 2010) for a variety of reasons, including coercive interrogation tactics (Kassin et al., 2003; King and Snook, 2009). However, in a criminal trial, a defendant's confession is one of the most influential forms of evidence that the prosecution can present (Kassin and Neumann, 1997; Lieberman et al., 2008; Schweitzer and Nuñez, 2018). For instance, Lieberman et al. (2008) demonstrated that among several types of evidence, the only type that participants perceived as more persuasive than a suspect's confession was DNA analysis. Even then, there are plenty of anecdotal instances in which law enforcement officials have ignored exculpatory DNA evidence in investigations when the suspect has confessed (e.g., the Central Park jogger case, Juan Rivera, the Norfolk Four; Duru, 2003; Leo and Davis, 2010). Furthermore, Appleby and Kassin (2016) conducted a series of jury studies involving conflicting DNA and confession evidence. Although participants were overall more likely to render a verdict in line with the DNA evidence, the authors also observed that perceptions of culpability and the proportion of guilty verdicts rose significantly when the prosecution presented a theory to explain the contradicting exculpatory DNA evidence (e.g., the DNA evidence only indicated that the defendant had not ejaculated).

Unfortunately, the phenomenon of false confessions is by no means a rare occurrence. Depending on particular definitions and methodology ${ }^{2}$, scholars estimate that false confessions contribute to $12-26 \%$ of wrongful convictions (Gudjonsson, 2003; Innocence Project, 2021; National Registry of Exonerations, 2020). Further research suggests that $73-81 \%$ of individuals who falsely confess are eventually convicted of the crime (Leo and Ofshe, 1998; Drizin and Leo, 2004). This type of evidence may be so problematic partly because jurors are unable to distinguish between true and false confessions (Kassin et al., 2005; Levine et al., 2010) and are unreceptive to the idea that

\footnotetext{
${ }^{2}$ The National Registry of Exonerations defines a false confession as "a statement made to law enforcement at any point during the proceedings which was interpreted or presented by law enforcement as an admission of participation in or presence at the crime, even if the statement was not presented at trial. A statement is not a confession if it was made to someone other than law enforcement. A statement that is not at odds with the defense is not a confession. A guilty plea is not a confession." In comparison, the Innocence Project's definition includes false admissions and other forms of self-incrimination in their definition of false confessions.
}

an innocent person would ever falsely admit to a crime (Leo and Davis, 2010; Blandon-Gitlin et al., 2011). In an attempt to safeguard against the serious implications of a false confession, some states have allowed expert witnesses to testify about the science concerning this type of evidence (Kassin, 2008; Fulero, 2010).

\section{Expert Testimony}

A small number of studies have investigated the effect that expert testimony has on jurors' perceptions of recanted confessions. Jurors themselves report that such testimony would assist in their evaluation of this form of evidence (e.g., Chojnacki et al., 2008; Costanzo et al., 2010). However, findings concerning expert testimony's actual influence on verdicts in confession trials are mixed (Blandon-Gitlin et al., 2011; Gomes et al., 2016; Henderson and Levett, 2016). For instance, a number of studies have observed no differences in verdicts between jurors who have and have not been presented with expert testimony in mock homicide trials (Moffa and Platania, 2007; Henderson and Levett, 2016, Study 2; Jones and Penrod, 2016). In comparison, Blandon-Gitlin et al. (2011) found that participants who read a trial transcript involving a recanted confession were less likely to render a guilty verdict after being exposed to expert testimony.

If working as intended, expert testimony should sensitize jurors to the quality of the confession (Cutler et al., 1989; Levett and Kovera, 2008), thus leading to fewer convictions when the confession is low quality (e.g., when several interrogation tactics known to elicit false confession have been used). However, rather than sensitizing jurors to variations in the quality of confession evidence, expert testimony may instead induce a general skepticism concerning confessions. For example, Woody and Forrest (2009) found that jurors presented with expert testimony concerning false confessions were significantly less likely to convict the defendant, regardless of whether a false evidence ploy was used in the interrogation. In a similar study involving mock jurors, Woestehoff and Meissner (2016, Study 3) manipulated the pressure and number of coercive interrogation tactics used in a defendant's confession, as well as the presence of expert testimony. Overall, jurors were less likely to convict the defendant when exposed to expert testimony. This effect held regardless of how much pressure was involved in the defendant's interrogation. Interestingly, Woestehoff and Meissner (2016) observed an effect of interrogation pressure independent of the expert witness; jurors given the high and medium-pressure conditions were significantly less likely to convict as compared to jurors who read about a low-pressure confession. These participants therefore appeared to be sensitive to variations in the confession evidence's strength without the help of expert testimony.

Overall, there are conflicting findings regarding the effectiveness of expert testimony in cases involving a recanted confession. One factor that may explain these contradictory results is the race of the defendant. As described below, previous research has suggested that defendant race may influence jurors' perceptions of the confession itself (Ratcliff et al., 2010; Pickel et al., 2013). 


\section{Race in the Criminal Courtroom}

An abundance of research examining the influence of defendant race has found that jurors often discriminate against defendants belonging to a racial minority (e.g., ForsterLee et al., 2006; Struckman-Johnson et al., 2008; Pickel et al., 2013). Specifically, jurors' perceptions of confession evidence appear to depend upon the defendant's race (Ratcliff et al., 2010; Pickel et al., 2013). Pickel et al. (2013) presented mock jurors with a confession video wherein the defendant's race was ambiguous. Jurors who were told the defendant was Arab American rated the confession as more voluntary and were more likely to convict than those who believed the defendant was White. In similar research, Ratcliff et al. (2010) found that participants shown a video of a confession believed that the confession was more voluntary, and that the suspect was more likely to be guilty, if the suspect was Asian or Black, as opposed to White.

Several studies have further observed the existence of an overall similarity-leniency bias within the courtroom, such that jurors perceive defendants of the same race more favorably than other-race defendants (see Mitchell et al., 2005; Devine and Caughlin, 2014 for meta-analyses). This similarity-leniency bias may be explained by social identity theory (SIT; Tajfel and Turner, 1986), which argues that people have a motivation to favor and prefer individuals belonging to their groups (rather than those outside of their groups) as a method of promoting a positive self-concept. In a criminal trial, social identity theory would therefore predict that jurors are more likely to acquit a defendant of the same race (and more likely to convict a defendant of a different race).

However, the watchdog hypothesis (Sargent and Bradfield, 2004) suggests that White jurors are motivated to protect against discrimination and thus pay more attention to legally relevant information when the defendant is Black. Using simulated vignettes describing a robbery trial, Sargent and Bradfield (2004) manipulated alibi evidence strength (Study 1), crossexamination effectiveness (Study 2), and defendant race, in two samples of White mock jurors. They found that White jurors were more sensitive to manipulations of alibi strength and cross-examination effectiveness when the defendant was Black as opposed to White. The authors argued that White jurors may have attended to this information more closely in an effort to be "watchdogs" against racism. In trials involving recanted confessions, jurors may therefore be more receptive to expert testimony (concerning the phenomenon of false confessions) when the defendant is Black as compared to White.

\section{Current Study}

Previous research has observed conflicting findings concerning the effect of expert testimony in trials involving recanted confessions. Furthermore, although research examining juror and defendant race has demonstrated a similarity-leniency bias (see Devine and Caughlin, 2014), Sargent and Bradfield (2004) suggest that White jurors may pay more attention to legally relevant evidence when the defendant is Black. The current study therefore aimed to examine the interactive effects of defendant race and expert testimony on jurors' perceptions of recanted confessions. Drawing upon previous research, we developed two hypotheses.

Hypothesis 1: Based on previous literature suggesting that jurors perceive confessions to be less voluntary for White defendants (e.g., Ratcliff et al., 2010), and other research demonstrating an outgroup bias in verdict decisions (e.g., Devine and Caughlin, 2014), we predicted a main effect for defendant race such that [predominantly White (United States Census Bureau, 2019)] participants would be more likely to convict the Black defendant than his White counterpart.

Hypothesis 2: However, in accordance with the watchdog hypothesis (Sargent and Bradfield, 2004), we predicted an interaction between defendant race and expert testimony for White participants. Specifically, White participants would render fewer convictions in conditions with expert testimony as compared to conditions with no expert testimony for the Black defendant (with no such effect for the White defendant), as this testimony is legally relevant information to which they could attend to be "watchdogs" against racism.

\section{MATERIALS AND METHODS}

\section{Participants}

Research has demonstrated that crowd sourced samples can be more heterogenous as compared to traditional undergraduate college samples (Paolacci et al., 2010; Paolacci and Chandler, 2014; Baker et al., 2016). We therefore recruited participants using Amazon's Mechanical Turk (MTurk). We compensated participants with $\$ 3$ for successfully completing the study. Although we had 1133 responses to our task, one participant did not give informed consent, 248 participants failed manipulation/attention checks ${ }^{3}, 235$ participants were ineligible for jury duty in the United States, and 58 participants quit the survey prior to completion. Our final sample therefore consisted of 591 jury-eligible community members (i.e., citizens of the United States who were at least 18 years old with no unpardoned felony conviction). Three-hundred and thirty-one (55.4\%) of the participants were women, 263 (44.1\%) were men, and three $(0.5 \%)$ identified as another gender. Participants' ages ranged from 19 to 69 years old $(M=36)$. Four-hundred and eighty-seven $(81.6 \%)$ of the participants were White, 51 (8.5\%) were Black, 27 (4.5\%) were Hispanic, 21 (3.5\%) were Asian, four (0.7\%) were Native American, and seven (1.2\%) identified as another race. Our participants' racial demographics are similar to what other researchers have observed using MTurk

\footnotetext{
${ }^{3}$ Sixty-two participants failed the manipulation check concerning defendant race, while 184 participants failed the manipulation check concerning the content of the expert's testimony. For attention checks, participants were instructed to select a particular response. Twenty-six participants failed the first attention check, 29 participants failed the second attention check, and 33 failed the third attention check.
} 
(e.g., Burnham et al., 2018), and are comparable to the general United States population (United States Census Bureau, 2019), although our sample contained a slightly lower percentage of individuals identifying as Black (8.5 vs. $13.4 \%$ ).

\section{Materials}

\section{Screening/Demographic Questionnaire}

We used a demographic questionnaire in order to screen participants to ensure that they were jury-eligible. Participants were also asked to provide information regarding their race and gender.

\section{Trial Transcript}

We used a trial transcript adapted from previous research (Kassin and Sommers, 1997; Sommers and Kassin, 2001; Henkel, 2008). The transcript involved a defendant charged with murdering his wife and neighbor. The prosecution argued that the defendant had arrived home to find his wife and neighbor together, and believing they were having an affair, he killed them in an act of jealousy. However, the defendant claimed that his wife and neighbor were already dead when he came home. The defendant had initially confessed to the crime, but later recanted the confession. Apart from this confession, the remaining evidence was circumstantial (e.g., a witness saw someone fleeing the crime scene who matched the general physical description of the defendant). The defendant testified that during his interrogation he was handcuffed to a desk in a small room for more than $5 \mathrm{~h}$ and claimed the interrogating officer had physically threatened him with his service weapon. The defendant also stated that he was experiencing an immense amount of stress and in a state of shock during the interrogation because he had learned of his wife's death only hours before. Finally, the defendant testified that the interrogating officer had repeatedly told him that his actions (killing his cheating spouse and her lover) were understandable, and that no one would blame him for what he did (i.e., minimization, Kassin and McNall, 1991). In each transcript, we manipulated the defendant's race (Black, White) and presence of expert testimony (present, not present). Defendant race was manipulated by including a color photograph [matched in a pilot study $(N=30)$ on perceived age, likeability, and attractiveness] of the defendant, along with varying his name (Charles Smith for the White defendant and Jamaal Washington for the Black defendant) to strengthen our race manipulation. Previous research has used names to manipulate race (e.g., Bertrand and Mullainathan, 2004; Widner and Chicoine, 2011; Alhabash et al., 2014), as names can reinforce racial stereotypes and elicit biased judgments (Bodenhausen and Wyer, 1985; Watson et al., 2011; Garcia and Abascal, 2016). In half of the transcripts, an expert witness specializing in confession research testified for the Defense. The expert primarily testified about two situational factors - minimization techniques and extended periods of time - that increase the likelihood of a false confession, both of which he noted were present in the defendant's confession and interrogation. The expert also discussed independent knowledge of the crime (underscoring the fact that the defendant's confession did not include details that only the true perpetrator of the crime would know), as well as the prevalence of wrongful convictions that involve a false confession.

\section{Jury Instructions}

Before and after the transcript, we provided participants with juror instructions adapted from the California Criminal Jury Instructions (Judicial Council of California Civil Jury Instructions, 2020). The instructions discussed the criteria for first-degree murder, as well as the lesser-included second-degree murder and voluntary manslaughter charges, and also informed participants about the burden of proof and reasonable doubt.

\section{Juror Questionnaire}

In accordance with the legal instructions, we first asked participants to render a dichotomous verdict concerning the first-degree murder charge (guilty/not guilty). Participants who selected not guilty were then asked to render a dichotomous verdict concerning a second-degree murder charge (guilty/not guilty). Participants who still selected not guilty were then finally asked to render a dichotomous verdict concerning a voluntary manslaughter charge (guilty/not guilty). Logistically, we felt this method most appropriately reflected how jurors decide verdicts in California, as a juror who renders a guilty verdict for firstdegree murder would not need to vote on the lesser-included offenses. We also asked participants to indicate on a scale from 1 (not at all) to 9 (very much) the degree to which they felt the defendant's confession was voluntary ("How voluntary was the defendant's confession?").

The questionnaire also included a manipulation check, which asked participants to identify the race of the defendant from a list of options. In conditions with expert testimony, we asked participants to identify what the expert witness testified about ("What was a factor that the false confession expert, Dr. Turner, discussed?") from a list of options to demonstrate that they had attended to this material. We embedded three other attention checks that required participants to select a specific response (e.g., “This is an attention check. Select Strongly Agree.").

\section{Procedure}

Participants were recruited from MTurk and completed the study online using Qualtrics survey software. Once participants had given informed consent, they were screened to ensure they met jury-eligibility requirements. We randomly assigned eligible participants to one of the four trial transcripts. Before and after reading the transcript, participants were provided with relevant legal instructions. After reading the transcript, participants responded to the juror questionnaire. Upon completion, participants were thanked, debriefed, and compensated. Participation in the study lasted approximately $30-$ $45 \mathrm{~min}$.

\section{RESULTS}

\section{Verdicts}

Tables 1-3 display a breakdown of verdicts by condition for the first-degree murder, second-degree murder, and voluntary 
TABLE 1 | First-degree murder verdicts by defendant race and expert testimony.

\begin{tabular}{lcccc}
\hline Defendant race & Expert testimony & Verdict & Frequency & Percent \\
\hline White & No Expert Testimony & Not guilty & 113 & $72.9 \%$ \\
& & Guilty & 42 & $27.1 \%$ \\
& Total & 155 & $100.0 \%$ \\
& \multirow{3}{*}{ Expert Testimony } & Not guilty & 105 & $72.9 \%$ \\
& & Guilty & 39 & $27.1 \%$ \\
& Total & 144 & $100.0 \%$ \\
Black & No Expert Testimony & Not guilty & 96 & $68.1 \%$ \\
& & Guilty & 45 & $31.9 \%$ \\
& Total & 141 & $100.0 \%$ \\
& \multirow{2}{*}{ Expert Testimony } & Not guilty & 120 & $79.5 \%$ \\
& & Guilty & 31 & $20.5 \%$ \\
& & Total & 151 & $100.0 \%$ \\
\hline
\end{tabular}

TABLE 2 | Second-degree murder verdicts by defendant race and expert testimony.

\begin{tabular}{lcccc}
\hline Defendant race & Expert testimony & Verdict & Frequency & Percent \\
\hline White & No Expert Testimony & Not guilty & 75 & $66.4 \%$ \\
& & Guilty & 38 & $33.6 \%$ \\
& Total & 113 & $100.0 \%$ \\
& \multirow{3}{*}{ Expert Testimony } & Not guilty & 77 & $73.3 \%$ \\
& & Guilty & 28 & $26.7 \%$ \\
\multirow{3}{*}{ Black } & Total & 105 & $100.0 \%$ \\
& \multirow{4}{*}{ No Expert Testimony } & Not guilty & 68 & $71.6 \%$ \\
& Guilty & 27 & $28.4 \%$ \\
& Expert Testimony & Total & 95 & $100.0 \%$ \\
& & Not guilty & 89 & $74.2 \%$ \\
& & Guilty & 31 & $25.8 \%$ \\
& & Total & 120 & $100.0 \%$ \\
\hline
\end{tabular}

TABLE 3 | Voluntary manslaughter verdicts by defendant race and expert testimony.

\begin{tabular}{lcccc}
\hline Defendant race & Expert testimony & Verdict & Frequency & Percent \\
\hline White & No Expert Testimony & Not guilty & 60 & $80.0 \%$ \\
& & Guilty & 15 & $20.0 \%$ \\
& Total & 75 & $100.0 \%$ \\
& \multirow{3}{*}{ Expert Testimony } & Not guilty & 51 & $66.2 \%$ \\
& & Guilty & 26 & $33.8 \%$ \\
& Total & 77 & $100.0 \%$ \\
Black & No Expert Testimony & Not guilty & 52 & $76.5 \%$ \\
& & Guilty & 16 & $23.5 \%$ \\
& Total & 68 & $100.0 \%$ \\
& \multirow{3}{*}{ Expert Testimony } & Not guilty & 70 & $78.7 \%$ \\
& & Guilty & 19 & $21.3 \%$ \\
& & Total & 89 & $100.0 \%$ \\
\hline
\end{tabular}

manslaughter charges, respectively. Table 4 summarizes the percentage of not guilty verdicts by verdict option for all participants as well as for White participants only. Prior to running the regression, we indicator coded our predictor variables $(0=$ no expert, $1=$ expert present, and $0=$ White defendant, 1 = Black defendant, respectively). We coded our ordinal outcome variable as $0=$ not guilty, $1=$ guilty of
TABLE 4 | Percentage of not guilty verdicts by charge.

\begin{tabular}{lcc}
\hline Charge & \multicolumn{2}{c}{$\%$ of Not guilty verdicts } \\
\cline { 2 - 3 } & Full sample & White participants \\
\hline First-degree murder & $72.6 \%$ & $74.5 \%$ \\
Second-degree murder & $52.0 \%$ & $53.3 \%$ \\
Voluntary manslaughter & $39.3 \%$ & $40.5 \%$ \\
\hline
\end{tabular}

manslaughter, 2 = guilty of second-degree murder, and 3 = guilty of first-degree murder. To test our hypotheses, we conducted an ordinal regression with verdict being regressed on expert testimony, defendant race, and the interaction between expert testimony and defendant race. Results revealed no significant main effect of expert testimony, $b=-0.04$, OR $=0.96,95 \% \mathrm{CI}$ $[0.64,1.45], W^{2}(1, N=591)=0.03, p=0.861$, or defendant race, $b=-0.12$, OR $=0.89,95 \%$ CI $[0.59,1.34], W^{2}(1, N=591)=0.33$ $p=0.568$. Additionally, the expert testimony by defendant race interaction was non-significant, $b=0.56, \mathrm{OR}=1.75,95 \% \mathrm{CI}[0.97$, 3.15], $W(1, N=591)=3.48, p=0.062$.

Because the watchdog hypothesis specifically involves White individuals (Sargent and Bradfield, 2004), we re-ran our initial regression using only White participants $(N=482)$. As before, we conducted an ordinal regression on verdict using expert testimony, defendant race, and the interaction as the predictor variables. Again, we observed no significant main effects of expert testimony, $b=-0.26$, OR $=0.77,95 \%$ CI $[0.49,1.21], W^{2}(1$, $N=482)=1.29, p=0.257$, or defendant race, $b=-0.35$, $\mathrm{OR}=0.70,95 \%$ CI $[0.44,1.11], W^{2}(1, N=482)=2.26$, $p=0.133$. However, there was a significant interaction between expert testimony and defendant race, $b=0.93, \mathrm{OR}=2.56$, $95 \%$ CI $[1.33,4.92], W^{2}(1, N=482)=7.9, p=0.005$. We probed this interaction for White participants by running two separate ordinal regressions with expert testimony as the predictor, splitting the data file based on defendant race. Analyses indicated that for White jurors, there was no effect of expert testimony when the defendant was White, $b=-0.26, \mathrm{OR}=0.77$, $95 \%$ CI $[0.49,1.21], W^{2}(1, N=245)=1.28, p=0.258$. In comparison, we observed a significant effect of expert testimony when the defendant was Black, $b=0.68, \mathrm{OR}=1.98,95 \% \mathrm{CI}$ $[1.23,3.17], W^{2}(1, N=237)=8.04, p=0.005$. The odds of White jurors rendering a not guilty verdict (versus other verdict options) for the Black defendant were approximately twice as high when given expert testimony as compared to when no such testimony was presented.

Using the hmisc package (Harrell, 2021) in R (R Core Team, 2021), we conducted a post hoc sensitivity analysis to provide an estimate of the smallest effect size that we would have sufficient power (i.e., 80\%) to detect. Analysis indicated that for an overall $\mathrm{N}$ of 590 , our design had a power of. 80 to detect an odds ratio of 1.52 , which is equivalent to a "small" effect size under Cohen's conventions (see Chen et al., 2010). Therefore, we appeared to be sufficiently powered to conduct our ordinal analyses.

\section{Voluntariness of Confession}

We conducted an exploratory analysis on participants' perceptions of how voluntary the defendant's confession 
was. We were interested in examining effects on voluntariness in particular because we felt this was a purer measure of jurors' perceptions of the confession itself. In comparison, participants' final verdicts could be influenced by a number of factors unrelated to the confession evidence (e.g., the circumstantial evidence presented at trial).

Overall, participants scored near the midpoint on their perceived voluntariness of the defendant's confession $(M=4.71$, $S D=2.57)$. We ran a $2 \times 2$ ANOVA to test the degree to which defendant race and expert testimony influenced this rating. Results revealed a significant main effect for expert testimony $\left[F(1,586)=4.76, p=0.03, \eta_{p}^{2}=0.008, w_{p}^{2}=0.006\right]$; participants who received expert testimony perceived the defendant's confession to be less voluntary $(M=4.48, S D=2.50)$ than those who did not $(M=4.94, S D=2.62)$. The main effect for defendant race was not significant $[F(1,586)=0.14$, $p=0.71$, partial $\left.\eta^{2}=0.001 w^{2} p \leq 0.001\right]$, nor was the interaction $\left[F(1,586)=2.17, p=0.14, \eta_{p}^{2}=0.004, w_{p}^{2}=0.002\right]$.

As above, we re-ran this analysis with only White participants. This test again revealed a small, significant main effect for expert testimony $\left[F(1,477)=4.00, p=0.046, \eta_{p}^{2}=0.008\right.$, $\left.w_{p}^{2}=0.006\right]$, qualified by a significant interaction between defendant race and expert testimony $[F(1,477)=4.20, p=0.041$, $\left.\eta_{p}^{2}=0.009, w_{p}^{2}=0.007\right]$; the main effect for defendant race was not significant $\left[F(1,477)=0.46, p=0.50\right.$, partial $\eta^{2}=0.001$, $\left.w_{p}^{2} \leq 0.001\right]$. To probe the interaction, we first compared the effects of expert testimony on voluntariness ratings by defendant race. Simple effects tests demonstrated that for those who read about a White defendant, voluntariness ratings did not differ significantly in the presence $(M=4.61, S D=2.45)$ or absence $(M=4.60, S D=2.66)$ of expert testimony, $t(242)=-0.04$, $p=0.98, d=0.01,95 \%$ CI $[-0.25,0.24]$. However, participants who read about a Black defendant were significantly less likely to perceive his confession as voluntary when they received expert testimony $(M=4.29, S D=2.52)$ as compared to when they did not $(M=5.23, S D=2.63), t(235)=2.83, p=0.005, d=0.37$, 95\% CI [0.11,0.63]. See Figure 1 for a visual display of this relationship. When probing the interaction the other way, we did not find significant effects for defendant race in either the expert testimony present $\{t(240)=1.01, p=0.315, d=0.13,95 \% \mathrm{CI}$ $[-0.12,0.38]\}$ or absent $\{t(237)=-1.86, p=0.064, d=0.24,95 \%$ CI $[-0.50,0.01]\}$ conditions.

\section{DISCUSSION}

The aim of this study was to explore the combined effects of defendant race and expert testimony on jurors' decisionmaking in trials involving a recanted confession. In line with the watchdog hypothesis (Sargent and Bradfield, 2004), when the defendant was Black, White jurors were significantly more likely to render a not guilty verdict when given expert testimony. In comparison, White jurors' verdicts were not significantly influenced by expert testimony in conditions involving White defendants. This same pattern was found for perceptions of the confession's voluntariness, although findings relating to the voluntariness measure require further confirmatory testing from future research.

Our results may demonstrate evidence of a sensitivity effect in situations involving a Black defendant and a confession. Given that jurors in the Black defendant condition convicted less often and perceived the confession as less voluntary, these jurors likely attended more to the expert testimony than did those in the White defendant condition. Doing so may have allowed the testimony to sensitize jurors to the issues related to the disputed confession (e.g., long period of time, minimization and maximization techniques employed, lack of independent knowledge of the crime, etc.). However, because we did not manipulate the strength of the confession, it is unclear whether the expert testimony truly sensitized jurors in these conditions. Instead, they may have simply become skeptical of all confession evidence. Given that earlier findings regarding expert testimony and confession evidence suggest that the mere presence of expert testimony (regardless of the presence of coercive interrogation tactics) could reduce reliance on confessions (Woody and Forrest, 2009), this was an important first step in establishing the presence of a watchdog effect. Future research should extend the current study's design with the inclusion of a confession quality (i.e., lower vs. higher number of coercive tactics present in the interrogation) manipulation. Doing so would allow for a better understanding of whether sensitivity or skepticism is occurring in these situations.

Because our sample was predominantly White, we predicted an overall similarity-leniency bias such that Black defendants would be more likely to be convicted than defendants who were White (Devine and Caughlin, 2014). Contrary to predictions,

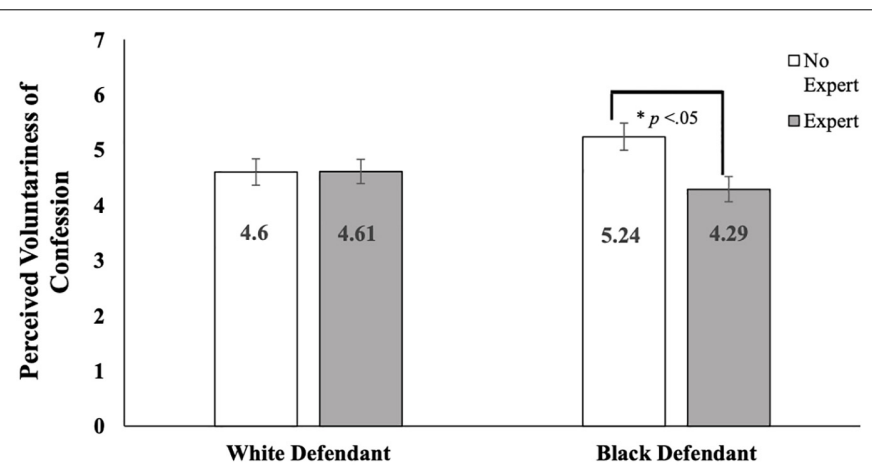

FIGURE 1 | Ratings of voluntariness of confession by defendant race and expert testimony for White participants. 
there was no significant main effect of defendant race on jurors' verdicts. Although this finding conflicts with research supporting the similarity-leniency hypothesis (e.g., Ugwuegbu, 1978; Sommers and Ellsworth, 2000; Devine and Caughlin, 2014), other research has also demonstrated null effects relating to defendant race (e.g., Braden-Maguire et al., 2005; Maeder et al., 2012; Yamamoto and Maeder, 2017).

There are a number of potential explanations for why we observed no significant overall effect of defendant race. According to the aversive racism framework (Schweitzer and Nuñez, 2018), the influence of racial bias is greatest in ambiguous situations (Dovidio and Gaertner, 1996 2000, 2004). In the current study, the legal instructions likely removed some of the ambiguity concerning participants' verdict decision, lessening the effect defendant race may have had (Pfeifer and Ogloff, 1991). Furthermore, a recent meta-analysis observed out-group bias in studies involving property crimes or adult sexual assaults, but much smaller (or non-existent) effects in studies using violent cases (Devine and Caughlin, 2014). Because our trial transcript involved a murder, future research should consider replicating the current study using other crimes, such as burglary.

Finally, our data were collected between June and December 2018. During this time, the police's unjust treatment of Black individuals became a salient topic in the media (e.g., Carney, 2016; Lopez, 2018; Scott, 2018). Our participants may therefore have been cognizant of the potential for such discrimination, particularly because the defendant claimed that he was threatened and coerced by police during his interrogation. Previous research has found that White jurors' bias against BIPOC defendants is minimized when racial issues are made salient during the trial (e.g., Cohn et al., 2009; Bucolo and Cohn, 2010). It is a strong possibility that cases involving alleged police misconduct are inherently race salient, leading jurors to correct for racial bias and resulting in a null effect of defendant race (Sommers and Ellsworth, 2000, 2001). It is important to note that following the death of George Floyd in May 2020, the topic of racial discrimination in the United States' justice system received unprecedented attention and media coverage. We encourage researchers to replicate and extend these findings to see what effect these recent events may have had in this context.

Similar to our results concerning defendant race, we observed no significant main effect of expert testimony on jurors' verdicts. This complements the work of Jones and Penrod (2016), as well as Moffa and Platania (2007), but contradicts a number of other studies that did observe an effect of expert testimony in trials involving recanted confessions (Woody and Forrest, 2009; Blandon-Gitlin et al., 2011; Woestehoff and Meissner, 2016). Related research concerning jurors' perceptions of secondary confessions has also observed no significant effect of expert testimony on verdicts (Neuschatz et al., 2012; Maeder and Pica, 2014).

In comparison to our results concerning expert testimony and verdict, there was a significant main effect of expert testimony on perceived voluntariness of the confession. One explanation for this pattern may be that although expert testimony lowered jurors' perceived voluntariness of the confession, they still viewed the confession itself as indicative of guilt. Researchers have used the fundamental attribution error to explain jurors' reluctance to discount disputed confession (e.g., Kassin and Sukel, 1997; Kassin and Gudjonsson, 2005). In our study, jurors may indeed have perceived the confession as less voluntary following expert testimony, but they still may have believed that overall, the defendant confessed because he was guilty (rather than because of the situational factors present). In similar research, Kassin and Wrightsman (1981) found instructions on the unreliability of coerced confessions significantly decreased participants' perceived voluntariness of the confession, but did not influence verdicts.

In their work, Sargent and Bradfield (2004) manipulated the strength of the defendant's alibi as well as the strength of the prosecutor's cross-examination ${ }^{4}$; future research should continue to examine the watchdog hypothesis by manipulating other types of evidence and/or expert testimony (such as expert testimony concerning police use of force or eyewitness identifications). Because the watchdog effect has now been demonstrated using both direct evidence (i.e., defendant's alibi) as well as triallevel phenomena (i.e., cross-examination and expert testimony), we tentatively predict that our observed effects would likely generalize to these other forms of evidence. Further, our results underscore the notion that there is a complex effect of race in the courtroom that goes beyond a simple similarity-leniency effect; we found White jurors to be more lenient to the racial outgroup when given expert testimony. As discussed above, it may be the case that, due to the increased public attention regarding racial discrimination in the legal system, the similarity-leniency effect is minimized (or outright reduced) in trials involving potential police misconduct. More work examining this issue, particularly sampling from BIPOC jurors, is needed to better understand these complexities. Based on these preliminary results, White jurors appear to either interpret or apply evidence differently depending upon the defendant's race, ultimately leading to different verdict decisions. Specifically, our findings suggest that attorneys should particularly consider the use of expert testimony in trials involving a BIPOC defendant and a recanted confession.

Finally, although we found evidence to suggest a watchdog effect, there are other possible explanations for our findings. In our study, White participants may have been more likely to use expert testimony in their verdict decisions when the defendant is Black as opposed to White not because they are paying more attention to legally relevant factors (as per the watchdog hypothesis), but because they are looking for a reason to acquit the Black defendant. This may be in an attempt to establish non-racist credentials (e.g., Effron and Conway, 2015) when evaluating a Black defendant, White participants may feel as though their moral standing is uncertain, and so make greater use of the expert testimony and subsequently acquit in order to demonstrate their egalitarianism. Future research could implement a detailed measure of comprehension of the expert's testimony. This would reveal whether participants comprehend

\footnotetext{
${ }^{4}$ In the "weak" cross-examination condition, participants read a case summary where the court reporters indicated the prosecution had presented ineffective cross-examinations of the defense witnesses. In the "strong" condition, the case summary described the prosecution as presenting an effective cross-examination that diminished the defense witnesses' credibility.
} 
the information better when the defendant is Black, or whether they simply use the expert testimony as a reason to acquit the Black defendant.

\section{Limitations}

Our study's methodology had a number of limitations. To begin, we used a written trial transcript, which limited ecological validity (Wenger and Bornstein, 2006). However, existing literature suggests that presentation mode does not significantly affect mock jurors' verdict decisions (Bornstein, 1999; Pezdek et al., 2010). Furthermore, our participants were likely aware that their responses had no true consequences, which may have influenced our findings (Bornstein and McCabe, 2005; Bornstein et al., 2017). Studying real jury trials would help to overcome this problem of consequentiality and may have led to different results. However, such a methodology would also introduce a host of additional issues regarding feasibility and internal validity.Like most jury research, we also only used a single trial transcript that had specific evidence and charges. Replications using additional cases would increase the generalizability of our results.

An additional ecological limitation of the current study is the lack of a deliberation component. Although research has demonstrated that the jury's final verdict is often predicted from individual verdicts (Kalven and Zeisel, 1966; Devine et al., 2007), other literature suggests that deliberation can influence jurors' bias (London and Nunez, 2000) and also affect jurors' cognitive processes when trying to reach a decision (Salerno and Diamond, 2010; Salerno et al., 2017). Sommers (2006) has further demonstrated that the racial composition of a jury can influence how jurors talk about race, which may be relevant to our results as our study involved a Black defendant in half of the conditions. Therefore, future research examining the watchdog hypothesis should likely involve a deliberation component.

Because the study was conducted online on MTurk, there was a lack of general control over the environment in which participants responded, which may have produced environmental confounds. However, we implemented manipulation and attention checks to ascertain data quality (e.g., Peer et al., 2014). Using MTurk also allowed for recruitment from a nationwide community sample (rather than relying on an undergraduate sample from a single university), which likely increased the generalizability of our results (Baker et al., 2016). Regardless, we still had a fairly racially homogenous sample, as response rates from BIPOC participants were low. We were therefore unable to do any proper comparisons based on juror race. Although the watchdog hypothesis focuses specifically on White jurors, future research needs to be conducted that explicitly examines BIPOC jurors' perceptions in the courtroom.

\section{REFERENCES}

Alhabash, S., Hales, K., Baek, J. H., and Oh, H. J. (2014). Effects of race, visual anonymity, and social category salience on online dating outcomes. Comput. Hum. Behav. 35, 22-32. doi: 10.1016/j.chb.2014.02.016

Appleby, S. C., and Kassin, S. M. (2016). When self-report trumps science: effects of confessions, DNA, and prosecutorial theories on perceptions

\section{CONCLUSION}

Our study examined the role of defendant race and the influence of expert testimony in the context of trials involving recanted confessions. To the best of our knowledge, this is the first study to examine the interactive effects of these variables. For White jurors, we observed an interaction between defendant race and the presence of expert testimony. There was no significant effect of expert testimony on verdict when the defendant was White, but White jurors were significantly less likely to find the Black defendant guilty (and perceive his confession as voluntary) when presented with expert testimony concerning false confessions. These findings support the existence of the watchdog hypothesis (Sargent and Bradfield, 2004), such that White jurors are more receptive to legally relevant evidence when the defendant is Black. To gain a stronger understanding of when this effect is elicited, future research should replicate the current study using other types of evidence and expert testimony.

\section{DATA AVAILABILITY STATEMENT}

The raw data supporting the conclusions of this article will be made available by the authors, without undue reservation.

\section{ETHICS STATEMENT}

The studies involving human participants were reviewed and approved by the Carleton University Research Ethics Board-B (CUREB-B) Carleton University. The patients/participants provided their written informed consent to participate in this study.

\section{AUTHOR CONTRIBUTIONS}

LE and EM contributed to the conception and design of the study and conducted the data analysis. LE organized the data collection and wrote the first draft of the manuscript. EM wrote the sections of the manuscript. Both authors contributed to manuscript revision, read, and approved the submitted version.

\section{FUNDING}

This research received funding from the American-Psychology Law Society's Diversity Research Award.

of guilt. Psychol. Public Policy Law 22, 127-140. doi: 10.1037/law000 0080

Baker, M. A., Fox, P., and Wingrove, T. (2016). Crowdsourcing as a forensic psychology research tool. Am. J. For. Psychol. 34, 37-50.

Bertrand, M., and Mullainathan, S. (2004). Are Emily and Greg more employable than Lakisha and Jamal? A field experiment on labor market discrimination. Am. Econ. Rev. 94, 991-1013. doi: 10.1257/0002828042002561 
Blandon-Gitlin, I., Sperry, K., and Leo, R. (2011). Jurors believe interrogation tactics are not likely to elicit false confessions: will expert witness testimony inform them otherwise? Psychol. Crime Law 17, 239-260. doi: 10.1080/ 10683160903113699

Bodenhausen, G. V., and Wyer, R. S. Jr. (1985). Effects of stereotypes on decision making and information-processing strategies. J. Pers. Soc. Psychol. 48, 267-282.

Bornstein, B. H. (1999). The ecological validity of jury simulations: is the jury still out? Law Hum. Behav. 23, 75-91. doi: 10.1023/A:1022326807441

Bornstein, B. H., Golding, J. M., Neuschatz, J., Kimbrough, C., Reed, K., Magyarics, C., et al. (2017). Mock juror sampling issues in jury simulation research: a meta-analysis. Law Hum. Behav. 41, 13-28. doi: 10.1037/lhb0000223

Bornstein, B. H., and McCabe, S. G. (2005). Jurors of the absurd? The role of consequentiality in jury simulation research. Florida State Univ. Law Rev. 32, 443-467.

Braden-Maguire, J., Sigal, J., and Perrino, C. S. (2005). Battered women who kill: variables affecting simulated jurors' verdicts. J. Fam. Violence 20, 403-408. doi: 10.1007/s10896-005-7801-0

Bucolo, D. O., and Cohn, E. S. (2010). Playing the race card: making race salient in defence opening and closing statements. Legal Criminol. Psychol. 15, 293-303. doi: 10.1348/135532508X400824

Burnham, M. J., Le, Y. K., and Piedmont, R. L. (2018). Who is Mturk? Personal characteristics and sample consistency of these online workers. Ment. Health Relig. Culture 21, 934-944. doi: 10.1080/13674676.2018.1486394

Carney, N. (2016). All lives matter, but so does race: black lives matter and the evolving role of social media. Hum. Soc. 40, 180-199. doi: 10.1177/ 0160597616643868

Chen, H., Cohen, P., and Chen, S. (2010). How big is a big odds ratio? Interpreting the magnitudes of odds ratios in epidemiological studies. Commun. Stat. Simul. Comput. 39, 860-864. doi: 10.1080/03610911003650383

Chojnacki, D. E., Cicchini, M. D., and White, L. T. (2008). An empirical basis for the admission of expert testimony on false confessions. Arizona State Law J. 40, $1-46$.

Cohn, E. S., Bucolo, D., Pride, M., and Sommers, S. R. (2009). Reducing White juror bias: the role of race salience and racial attitudes. J. Appl. Soc. Psychol. 39, 1953-1973. doi: 10.1111/j.1559-1816.2009.00511.x

Costanzo, M., Shaked-Schroer, N., and Vinson, K. (2010). Juror beliefs about police interrogations, false confessions, and expert testimony. J. Empir. Legal Stud. 7, 231-247. doi: 10.1111/j.1740-1461.2010.01177.x

Cutler, B. L., Penrod, S. D., and Dexter, H. R. (1989). The eyewitness, the expert psychologist, and the jury. Law Hum. Behav. 13, 311-332. doi: 10.1007/ BF01067032

Devine, D. J., Buddenbaum, J., Houp, S., Stolle, D. P., and Studebaker, N. (2007). Deliberation quality: a preliminary examination in criminal juries. J. Empir. Legal Stud. 4, 273-303. doi: 10.1111/j.1740-1461.2007.00089.x

Devine, D. J., and Caughlin, D. E. (2014). Do they matter? A meta-analytic investigation of individual characteristics and guilt judgments. Psychol. Public Policy Law 20, 109-134. doi: 10.2466/pr0.1997.81.2.679

Dovidio, J. F., and Gaertner, S. L. (2000). Aversive racism and selection decisions: 1989 and 1999. Psychol. Sci. 11, 315-319. doi: 10.1111/1467-9280.00262

Dovidio, J. F., and Gaertner, S. L. (1996). Affirmative action, unintentional racial biases, and intergroup relations. J. Soc. Issue. 52, 51-75. doi: 10.1111/j.15404560.1996.tb01848.x

Dovidio, J. F., and Gaertner, S. L. (2004). "Aversive racism," in Advances in Experimental Social Psychology, Vol. 36, ed. M. P. Zanna (San Diego, CA: Academic Press), 1-52.

Drizin, S., and Leo, R. (2004). The problem of false confessions in the post-DNA world. N. Carolina Law Rev. 82, 891-1007.

Duru, N. J. (2003). The Central Park Five, the Scottsboro Boys, and the myth of the bestial black man. Cardozo Law Rev. 25, 1315-1366.

Effron, D. A., and Conway, P. (2015). When virtue leads to villainy: advances in research on moral self-licensing. Curr. Opin. Psychol. 6, 32-35.

ForsterLee, R., ForsterLee, L., Horowitz, I. A., and King, E. (2006). The effects of defendant race, victim race, and juror gender on evidence processing in a murder trial. Behav. Sci. Law 24, 179-198. doi: 10.1002/bsl.675

Fulero, S. M. (2010). Admissibility of expert testimony based on the Grisso and Gudjonsson scales in disputed confession cases. J. Psychiatry Law 38, 193-214. doi: $10.1177 / 009318531003800109$
Garcia, D., and Abascal, M. (2016). Colored perceptions: racially distinctive names and assessments of skin color. Am. Behav. Sci. 60, 420-441. doi: 10.1177/ 0002764215613395

Gomes, D. M., Stenstrom, D. M., and Calvillo, D. P. (2016). Examining the judicial decision to substitute credibility instructions for expert testimony on confessions. Legal Criminol. Psychol. 21, 319-331. doi: 10.1111/lcrp.12068

Gudjonsson, G. H. (2003). The Psychology of Interrogations and Confessions: A Handbook. Chichester: John Wiley \& Sons.

Harrell, F. (2021). HmiscL Version 4.5-0.

Henderson, K. S., and Levett, L. M. (2016). Can expert testimony sensitize jurors to variations in confession evidence? Law Hum. Behav. 40, 638-649. doi: 10.1037/ lhb0000204

Henkel, L. A. (2008). Jurors' reactions to recanted confessions: do the defendant's personal and dispositional characteristics play a role? Psychol. Crime Law 14, 565-578. doi: 10.1080/10683160801995247

Innocence Project (2021). Research Resources. Available online at: https:// innocenceproject.org/research-resources/

Jones, A. M., and Penrod, S. (2016). Can expert testimony sensitize jurors to coercive interrogation tactics? J. For. Psychol. Pract. 16, 393-409. doi: 10.1080/ 15228932.2016.1232029

Judicial Council of California Civil Jury Instructions (2020). Available online at: https://www.courts.ca.gov/partners/juryinstructions.htm (accessed January, 2019).

Kalven, H. Jr., and Zeisel, H. (1966). The American Jury. Chicago: University of Chicago Press.

Kassin, S. M. (2008). False confessions: causes, consequences, and implications for reform. Curr. Direct. Psychol. Sci. 17, 249-253. doi: 10.1111/j.1467-8721.2008. 00584.x

Kassin, S. M., Goldstein, C. C., and Savitsky, K. (2003). Behavioral confirmation in the interrogation room: on the dangers of presuming guilt. Law Hum. Behav. 27:187. doi: 10.1023/a:1022599230598

Kassin, S. M., and Gudjonsson, G. H. (2005). True crimes, false confessions. Sci. Am. Mind 16, 24-31.

Kassin, S. M., and Kiechel, K. L. (1996). The social psychology of false confessions: compliance, internalization, and confabulation. Psychol. Sci. 7, 125-128. doi: 10.1111/j.1467-9280.1996.tb00344.x

Kassin, S. M., and McNall, K. (1991). Police interrogations and confessions. Law Hum. Behav. 15, 233-251. doi: 10.1007/BF01061711

Kassin, S. M., Meissner, C. A., and Norwick, R. J. (2005). "I'd know a false confession if I saw one": a comparative study of college students and police investigators. Law Hum. Behav. 29:211. doi: 10.1007/s10979-005-2416-9

Kassin, S. M., and Neumann, K. (1997). On the power of confession evidence: an experimental test of the fundamental difference hypothesis. Law Hum. Behav. 21:469. doi: 10.1023/A:1024871622490

Kassin, S. M., and Sommers, S. R. (1997). Inadmissible testimony, instructions to disregard, and the jury: substantive versus procedural considerations. Pers. Soc. Psychol. Bull. 23, 1046-1054. doi: 10.1177/01461672972310005

Kassin, S. M., and Sukel, H. (1997). Coerced confessions and the jury: an experimental test of the "harmless error" rule. Law Hum. Behav. 21, 27-46. doi: 10.1023/A:1024814009769

Kassin, S. M., and Wrightsman, L. S. (1981). Coerced confessions, judicial instruction, and mock juror verdicts. J. Appl. Soc. Psychol. 11, 489-506. doi: 10.1111/j.1559-1816.1981.tb00838.x

King, L., and Snook, B. (2009). Peering inside a Canadian interrogation room: an examination of the Reid model of interrogation, influence tactics, and coercive strategies. Crim. Just. Behav. 36, 674-694. doi: 10.1177/00938548093 35142

Leo, R., and Ofshe, R. (1998). The consequences of false confessions: deprivations of liberty and miscarriages of justice in the age of psychological interrogation. J. Crim. Law Criminol. 88, 429-496. doi: 10.2307/1144288

Leo, R. A., and Davis, D. (2010). From false confession to wrongful conviction: seven psychological processes. J. Psychiatry Law 38, 9-56. doi: 10.1177/ 009318531003800103

Levett, L. M., and Kovera, M. B. (2008). The effectiveness of opposing expert witnesses for educating jurors about unreliable expert evidence. Law Hum. Behav. 32, 363-374. doi: 10.1007/s10979-007-9113-9

Levine, T. R., Kim, R. K., and Blair, J. P. (2010). (In) accuracy at detecting true and false confessions and denials: an initial test of a projected motive model of 
veracity judgments. Hum. Commun. Res. 36, 82-102. doi: 10.1111/j.1468-2958. 2009.01369.x

Lieberman, J. D., Carrell, C. A., Miethe, T. D., and Krauss, D. A. (2008). Gold versus platinum. Psychol. Public Policy Law 14, 27-62. doi: 10.1037/1076-8971.14.1.27

Lopez, G. (2018). There Are Huge Racial Disparities in How US Police Use Force. Washington, DC: Vox Media.

London, K., and Nunez, N. (2000). The effect of jury deliberations on jurors' propensity to disregard inadmissible evidence. J. Appl. Psychol. 85, 932-939. doi: 10.1037/0021-9010.85.6.932

Maeder, E., Dempsey, J., and Pozzulo, J. (2012). Behind the veil of juror decision making: testing the effects of Muslim veils and defendant race in the courtroom. Crim.Justice Behav. 39, 666-678. doi: 10.1177/0093854812436478

Maeder, E. M., and Pica, E. (2014). Secondary confessions: the influence (or lack thereof) of incentive size and scientific expert testimony on jurors' perceptions of informant testimony. Law Hum. Behav. 38, 560-568. doi: 10. 1037/lhb0000106

Mitchell, T. L., Haw, R. M., Pfeifer, J. E., and Meissner, C. A. (2005). Racial bias in mock juror decision-making: a meta-analytic review of defendant treatment. Law Hum. Behav. 29, 621-637. doi: 10.1007/s10979-005-8122-9

Moffa, M. S., and Platania, J. (2007). Effects of expert testimony and interrogation tactics on perceptions of confessions. Psychol. Rep. 100, 563-570. doi: 10.2466/ pr0.100.2.563-570

National Registry of Exonerations (2020). Exonerations in 2019. Ann Arbor: University of Michigan Law School.

Neuschatz, J. S., Wilkinson, M. L., Goodsell, C. A., Wetmore, S. A., Quinlivan, D. S., and Jones, N. J. (2012). Secondary confessions, expert testimony, and unreliable testimony. J. Police Crim. Psychol. 27, 179-192. doi: 10.1007/s11896-0129102-x

Paolacci, G., and Chandler, J. (2014). Inside the Turk: understanding Mechanical Turk as a participant pool. Curr. Direct. Psychol. Sci. 23, 184-188. doi: 10.1177/ 0963721414531598

Paolacci, G., Chandler, J., and Ipeirotis, P. G. (2010). Running experiments on Amazon Mechanical Turk. Judgment Decis. Making 5, 411-419.

Pezdek, K., Avila-Mora, E., and Sperry, K. (2010). Does trial presentation medium matter in jury simulation research? Evaluating the effectiveness of eyewitness expert testimony. Appl. Cogn. Psychol. 24, 673-690. doi: 10.1002/acp.1578

Peer, E., Vosgerau, J., and Acquisti, A. (2014). Reputation as a sufficient condition for data quality on Amazon Mechanical Turk. Behav. Res. Methods 46, 1023 1031. doi: 10.3758/s13428-013-0434-y

Pfeifer, J. E., and Ogloff, J. R. (1991). Ambiguity and guilt determinations: a modern racism perspective 1. J. Appl. Soc. Psychol. 21, 1713-1725.

Pickel, K. L., Warner, T. C., Miller, T. J., and Barnes, Z. T. (2013). Conceptualizing defendants as minorities leads mock jurors to make biased evaluations in retracted confession cases. Psychol. Public Policy Law 19:56. doi: 10.1037/ a0029308

R Core Team (2021). R: A Language and Environment for Statistical Computing. Vienna: R Foundation for Statistical Computing.

Ratcliff, J. J., Lassiter, G. D., Jager, V. M., Lindberg, M. J., Elek, J. K., and Hasinski, A. E. (2010). The hidden consequences of racial salience in videotaped interrogations and confessions. Psychol. Public Policy Law 16:200. doi: 10.1037/ a0018482

Redlich, A. D., Summers, A., and Hoover, S. (2010). Self-reported false confessions and false guilty pleas among offenders with mental illness. Law Hum. Behav. 34, 79-90. doi: 10.1007/s10979-009-9194-8

Salerno, J. M., Bottoms, B. L., and Peter-Hagene, L. C. (2017). Individual versus group decision making: jurors' reliance on central and peripheral information to evaluate expert testimony. PLoS One 12:e0183580. doi: 10.1371/journal.pone. 0183580

Salerno, J. M., and Diamond, S. S. (2010). The promise of a cognitive perspective on jury deliberation. Psychon. Bull. Rev. 17, 174-179. doi: 10.3758/PBR.17.2.174

Sargent, M. J., and Bradfield, A. L. (2004). Race and information processing in criminal trials: does the defendant's race affect how the facts are evaluated? Pers. Soc. Psychol. Bull. 30, 995-1008. doi: $10.1177 / 0146167204265741$
Scott, E. (2018). Only One-Third of African Americans Say They Have Confidence in the Police. Killings Like Alton Sterling's are Part of the Reason. Washington, DC: Washington Post.

Schweitzer, K., and Nuñez, N. (2018). What evidence matters to jurors? The prevalence and importance of different homicide trial evidence to mock jurors. Psychiatry Psychol. Law 25, 437-451. doi: 10.1080/13218719.2018.1437666

Sommers, S. R. (2006). On racial diversity and group decision making: identifying multiple effects of racial composition on jury deliberations. J. Pers. Soc. Psychol. 90, 597-612. doi: 10.1037/0022-3514.90.4.597

Sommers, S. R., and Ellsworth, P. C. (2000). Race in the courtroom: perceptions of guilt and dispositional attributions. Pers. Soc. Psychol. Bull. 26, 1367-1379. doi: $10.1177 / 0146167200263005$

Sommers, S. R., and Ellsworth, P. C. (2001). White juror bias: an investigation of prejudice against Black defendants in the American courtroom. Psychol. Public Policy Law 7:201. doi: 10.1037/1076-8971.7.1.201

Sommers, S. R., and Kassin, S. M. (2001). On the many impacts of inadmissible testimony: selective compliance, need for cognition, and the overcorrection bias. Pers. Soc. Psychol. Bull. 27, 1368-1377. doi: 10.1177/01461672012710012

Struckman-Johnson, C., Miller, M. G., and Struckman-Johnson, D. (2008). Effects of Native American race, intoxication, and crime severity on judgments of guilt. J. Appl. Soc. Psychol. 38, 1981-1992. doi: 10.1111/j.1559-1816.2008.00376.x

Tajfel, H., and Turner, J. C. (1986). "The social identity theory of intergroup behavior," in Psychology of Intergroup Relations, eds S. Worchel and W. Austin (Chicago, IL: Nelson-Hall).

Ugwuegbu, D. C. E. (1978). Racial and evidential factors in juror attribution of legal responsibility. J. Exp. Soc. Psychol. 15, 133-146. doi: 10.1016/0022-1031(79) 90025-8

United States Census Bureau (2019). ACS Demographic and Housing Estimates. Available online at: https://data.census.gov/

Watson, S., Appiah, O., and Thornton, C. G. (2011). The effect of name on preinterview impressions and occupational stereotypes: the case of black sales job applicants. J. Appl. Soc. Psychol. 41, 2405-2420. doi: 10.1111/j.1559-1816.2011. 00822.x

Wenger, A. A., and Bornstein, B. H. (2006). The effects of victim's substance use and relationship closeness on mock jurors' judgments in an acquaintance rape case. Sex Roles 54, 547-555. doi: 10.1007/s11199-006-9014-2

Widner, D., and Chicoine, S. (2011). It's all in the name: employment discrimination against Arab Americans. Sociol. Forum 26, 806-823. doi: 10. 1111/j.1573-7861.2011.01285.x

Woestehoff, S. A., and Meissner, C. A. (2016). Juror sensitivity to false confession risk factors: dispositional vs. situational attributions for a confession. Law Hum. Behav. 40:564. doi: 10.1037/lhb0000201

Woody, W. D., and Forrest, K. D. (2009). Effects of false-evidence ploys and expert testimony on jurors' verdicts, recommended sentences, and perceptions of confession evidence. Behav. Sci. Law 27, 333-360.

Yamamoto, S., and Maeder, E. M. (2017). Defendant and juror race in a necessity case: an ultimate attribution error. J. Ethn. Crim. Justice 15, 270-284. doi: $10.1080 / 15377938.2017 .1347542$

Conflict of Interest: The authors declare that the research was conducted in the absence of any commercial or financial relationships that could be construed as a potential conflict of interest.

Publisher's Note: All claims expressed in this article are solely those of the authors and do not necessarily represent those of their affiliated organizations, or those of the publisher, the editors and the reviewers. Any product that may be evaluated in this article, or claim that may be made by its manufacturer, is not guaranteed or endorsed by the publisher.

Copyright (c) 2021 Ewanation and Maeder. This is an open-access article distributed under the terms of the Creative Commons Attribution License (CC BY). The use, distribution or reproduction in other forums is permitted, provided the original author(s) and the copyright owner(s) are credited and that the original publication in this journal is cited, in accordance with accepted academic practice. No use, distribution or reproduction is permitted which does not comply with these terms. 